\title{
Quantitative Real-time Polymerase Chain Reaction for Tracking Microbial Gene Expression in Complex Environmental Matrices
}

\author{
Vijay J. Gadkar and Martin Filion* \\ Department of Biology, Université de Moncton, \\ 18 Antonine-Maillet, Moncton, NB E1A 3E9 Canada
}

\begin{abstract}
Environmental matrices are highly diverse in their composition and range from simple (e.g. water) to highly complex (e.g. organic soils/biosolids). Analysis of microbial gene expression from such substrates is done for variety of purposes which could range from bio-surveillance to elucidation of biological function of a target microbe. Quantitative real-time PCR (RT-qPCR) has become a technique of choice for studying such bio-processes, due to its unique ability to both detect and quantify a target transcript in real-time. Challenges in extracting inhibitorfree, structurally intact RNA, amenable for a sensitive technique like RT-qPCR, has however proved to be a major impediment in our ability to rigorously implement this highly versatile technology. Despite these 'substrate defined' limitations, many attempts have been made to implement the RT-qPCR technology. Efforts like these have given us invaluable insight into the expression status of a particular transcript and hence, the biological functioning of the microbe, specifically under natural in situ conditions. As a result, it has enhanced our understanding of the role and diversity of many microbial populations which, previously was not possible using conventional molecular approaches. In this article, we have sought to summarize such technical problems faced by molecular environmental microbiologist and solutions developed to mitigate those challenges.
\end{abstract}

\section{Introduction}

The key to studying gene expression quantitatively in environmental samples lies in one's ability to effectively and most importantly, specifically detect messenger RNA (mRNA), corresponding to the activity of interest. In this regard, the use of reverse transcription (RT) in conjunction with quantitative real-time polymerase chain reaction (qPCR) has become a method of choice for quantifying specific mRNA's (Filion, 2012).

The unique ability of the RT-qPCR based method to analyse large number of samples rapidly, with high degree of sensitivity and specificity, makes it a logical choice over other forms of RNA detection methodologies for example Northern blotting, in situ hybridization, RNase protection assays and semi-quantitative RT-PCR analyses amongst others. Some of the aforementioned non-qPCR methods are highly laborious and time consuming to perform, making them unsuitable for high-throughput experimental designs.

*Corresponding author: Email: martin.filion@umoncton.ca
Moreover, some of them, for example RNase protection assay and Northern blotting, have a lower threshold for detection compared with RT-qPCR (Sharkey et al., 2004). In summary, RT-qPCR is a technique of choice to detect target mRNA, if high degree of specificity, sensitivity and rapidity is desired. This article focuses on the methods, variants and technical limitation in quantifying mRNA's from complex environmental matrices.

\section{Microbial gene expression in environmental matrices} Detection and monitoring of microbial gene expression from an environmental sample has become an integral part of microbial ecology, bioremediation, biothreat analysis and diversity monitoring, amongst others (Sharkey et al., 2004). While there are several molecular tools available to analyse microbial gene expression per se (Fleming and Sayler, 1995), the introduction of the RT-qPCR technology adds a very different dimension, not afforded by any of the earlier techniques (Sharkey et al., 2004). With RT-qPCR technology, we have the unique ability to perform two specific functions simultaneously - monitor and quantify transcripts from target microbes, all under real-time conditions. The ease by which these two functions can be implemented by RTqPCR, has significantly enhanced our ability to understand the microbial processes occurring under natural conditions at such fine scale and resolution, not previously afforded by any of the known conventional gene targeting techniques.

Analysing microbial gene expression in an environmental matrix involves multifaceted handling and processing steps. The complexity of these initial steps is heavily dependent on the type of matrix in question. While there are simple matrices generated through 'controlled' experimental conditions, there are myriad of matrices one has to contend with, especially naturally sourced, starting from simple (e.g. water) to highly diverse and complex types (e.g. soil, raw sewage/biosolids and food). Since each of the aforementioned matrices possess different levels of compositional complexity which, in most cases is poorly defined, one's ability to reliably implement a sensitive technology like RT-qPCR, has hinged on one major factor - 'pre-processing' of target matrices. This, in other words, implies extraction of target components from the matrix in such forms that, it becomes amenable for RT-qPCR analysis. In practical terms, this involves the use of specific RNA extraction protocols which, in principle are not only optimized for an efficient recovery of nucleic acids (RNA in the present context), but are also capable of mitigating coextraction of endogenous confounding substances. These 'confounding' substances or inhibitors could be broadly defined as chemical moieties which, directly/indirectly interact with the components of the RT-qPCR reaction, leading to dampening of the final fluorescence signal. Such undesirable interactions invariably lead to an aberrant, 
and in many instances, an irreproducible gene expression quantification pattern (Suslov and Steindler, 2005).

Based on the wide diversity and hence the compositional complexity of environmental matrices per se, the array of such chemical inhibitors, documented till date, have been extremely vast (Wilson, 1997). These inhibitors, whose list is continually increasing, has an amazing range of diversity, from simple forms of heavy metals, commonly found in food/water-based matrices (Kreader, 1996; ljzerman et al., 1997), to the highly amorphous 'brown contaminating' substances, endemic to organic/sedimentary soils (Watson and Blackwell, 2000). Developing a viable RNA extraction protocol, capable of mitigating the effects of these endogenous inhibitory substances from each type of environmental matrix documented till date, is one major challenge faced by microbiologists working in this area of research. This is in sharp contrast to the wide scale application of RT-qPCR technology in other areas of microbial research, where inhibitor mitigation is easily achieved through the use of highly controlled/defined microbial cultivation substrates (e.g. artificial growth media) and a well-optimized RNA extraction protocol. Since it is impossible to 'dictate' the composition of an environmental matrix, especially those sourced naturally, the only option till date has been to manipulate/optimize the nucleic acid extraction protocols, so that a high quality, inhibitor-free RNA, compatible to the sensitive requirements of RTqPCR, is obtained. This, however, has proven to be a major challenge, since developing highly optimized protocols for each type of matrix, or class of matrices, is not only technically impossible, but also logistically impractical. In summary, this 'substrate defined' technical limitation, is a major bottleneck in our ability to rigorously implement the highly versatile RT-qPCR technology in environmental microbiology. Achieving a minimal 'quality benchmark' for this first and highly critical pre-processing step, has been a major and a continual challenge for environmental microbiologist.

In the subsequent sections, we aim to describe the technical challenges faced by many molecular environmental microbiologists interested in analysing microbial gene expression from environmental matrices, especially complex ones. Some of the areas covered include different type of RNA extraction methodologies, the invariant problem of endogenous inhibitors (which are co-extracted with RNA), common strategies employed to mitigate the effects of the same, finally followed by representative examples of specific environmental matrices namely soil, food/water and sludge/biosolids where RT-qPCR has successfully been implemented to quantify microbial gene expression.

\section{Problems in extracting RNA from environmental matrices and quality issues}

The first step towards analysing gene expression in any system is the invariant process of extracting RNA using an extraction protocol, optimized to yield high-quality, intact RNA. Low-quality RNA may compromise the derived expression results as previously observed (Raeymarkers, 1993; Imbeaud et al., 2005). Developing an optimized RNA extraction protocol, suitable for a wide-range or even a subset of environmental matrices with a common compositional makeup, has been a major challenge for researchers. Notwithstanding the availability of 'off the shelf' commercial kits capable of extracting high quality total RNA from environmental samples, the end user still has to empirically test a particular kit's suitability on his/her target matrix. This in many cases is extremely cumbersome and especially difficult if the sample amounts are exceedingly limiting. Moreover, commercial kits are only customized to work optimally for certain matrix type(s) and thus, may not be suitable for a particular user-defined matrix. Also, if the experimental set-up demands a high throughput RNA extraction, the overall cost of nucleic acid preparation can be a major deciding factor for a user to take into consideration.

The inclusion of a robust internal/external extraction control(s), is one way to circumvent the issue of variable extraction efficiencies between different extraction protocols, as previously reported (Hoorfar et al., 2003, 2004; Nolte 2004; van Doorn et al., 2009). However, the unavailability of an universal external control(s), specifically designed for environmental matrices, at least until recently (González-Escalona et al., 2009; Deer et al., 2010; DeCoste et al., 2011), and lack of unanimity amongst researchers on the choice of an optimal internal control, are some of the technical bottlenecks which have prevented researchers to implement testing RNA extraction protocols, either user developed or commercially available kits, in order to test their suitability for a particular matrix or class of matrices.

\section{RNA extraction protocols}

Although many protocols for extracting genomic DNA from environmental samples have been established till date (Bakken and Lindahl, 1995; Bakken and Frostegård, 2006), developing protocols capable of yielding high-quality, intact mRNA from the same substrate, remains a major obstacle. This is primarily due to the extreme labiality of the mRNA per se, especially of the prokaryotic origin which has a very short (in minutes) half-life (Takayama and Kjelleberg, 2000). Of the limited number of RNA extraction protocols developed till date for environmental matrices, one is able to always infer a well defined logical work flow. This work flow could be at best described into two steps: (a) cell lysis and release of RNA into the aqueous solution and (b) selective elution/precipitation of RNA. Any improvements to the current extraction protocols or development of new ones have always focused on modifying substeps within these two main steps.

The first step in extracting any RNA target is its release, preferably complete from the living cells. An inefficient or even an incomplete lysis could result in low or unrepresentative RNA amounts which, if submitted to RT-qPCR analysis would give either an aberrant or irreproducible gene expression pattern (Smith et al., 2006). Cell lysis is easily achieved in simple matrices (e.g. water) however; this has proven to be extremely difficult for highly complex environmental matrices like sludge, natural soil and unprocessed food. This difficulty is most probably attributed to the components of the complex matrix which bind/adsorb the target components hence, making it difficult to access the cells for a complete or at least a representative lysis (Hahn et al., 1990). Cell lysis is easily achieved through the use of chaotropic agents capable of permeabilizing the cells in simple matrices such as food (e.g. yoghurt) and water. Some of the commonly used agents include detergents such as sodium lauryl sulfate (SLS), lauryl sarcosyl and Triton $\mathrm{X}-100$, EDTA and lysozyme, amongst others (reviewed 
by Bakken and Frostegård, 2006). Since the major goal is to isolate RNA, these disrupting agents are used in combination with chemicals which inhibit the activity of the ubiquitously present RNase's which are released post cell lysis into the extraction solution. Some of the most commonly used agents include: lithium chloride ( $\mathrm{LiCl})$, cetyl-trimethyl ammonium bromide (CTAB), guanidinium thiocyanate $(\mathrm{GdnHCl})$ and guanidine isothocyanate (GTC) (Sambrook and Russel, 2001). Complex matrices like soil and biosolids require a harsh physical disruption to release the microbial RNA contents into the extraction media (reviewed by Bakken and Frostegård, 2006). Some of the commonly employed methods to achieve this include, but are not limited to, mortar grinding with/without liquid nitrogen (Zhou et al., 1996; Frostegård et al., 1999; Hurt et al., 2001) and bead beating (Bürgmann et al., 2001). The physical disruption is usually carried out in the presence of the aforementioned chaotropic agents so that, post cell disruption, the released nucleic acids (total RNA) is not subject to RNase mediated degradation. Addition of diethyl pyrocarbonate (DEPC), a potent inhibitor of RNases, directly in the extraction buffer, has also been described for matrices which are known to contain high amounts of endogenous RNases (Bleve et al., 2003). While there are many 'home brew' recipes for RNA extraction from environmental matrices (Ogram et al., 1995; Bürgmann et al., 2001; Hurt et al., 2001), many commercial kits are now increasingly becoming available which work on a pre-defined environmental matrix; for example, the Mo Bio water and soil RNA extraction systems from Mo Bio Laboratories (Carlsbad, CA, USA) or the ZR soil/faecal RNA extraction kit from Zymo Research Corp (Irvine, CA, USA), amongst few others. Owing to proprietary and intellectual concerns, the exact description of the composition of the solutions used in most commercial kits is not always available.

\section{Quality of RNA}

The RNA obtained following extraction is highly unstable and susceptible to degradation by endogenous RNase's (Bustin, 2002, 2005), especially mRNAs which are several kilobases long. Apart from this, degradation could also occur due to handling errors and improper storage of the sample under suboptimal temperature conditions (Schoor et al., 2003). Owing to the inherent chemical instability and its ability to get degraded due to base- or enzyme-catalysed hydrolysis, assessment of integrity of the extracted RNA is the first step in ensuring that the RNA submitted to RTqPCR analysis would result in a reproducible data. For that, the general criteria for RNA integrity, irrespective from which environmental matrix it has been extracted from, could be summarized as:

- $A_{260 \mathrm{~nm}} / A_{280 \mathrm{~nm}}$ spectrophotometric absorbance value $>1.8$;

- free of or extremely low genomic DNA contamination;

- free of enzymatic inhibitors of the reverse transcriptase enzyme and other enzymatic components of the RTqPCR reaction;

- free of divalent ions and other co-factors which affect PCR reaction;

- low amounts/free of endogenous nucleases.
Conventional methods for RNA assessment are often not sensitive enough and also not specific enough for singlestranded RNA (Fleige and Pfaffl, 2006). This makes it difficult to assess the quality of extracted RNA from a wide range of environmental matrices. The interference from other nontarget components during spectrophotometric assessment which include genomic DNA, proteins and other chemical moieties, also confound the true quality of the RNA. The conventional methods to assess RNA integrity can be done by classical denaturing agarose gel assessment, spectrophotometric assessment at multiple UVIVIS range wavelengths using a conventional spectrophotometer or a NanoDrop ${ }^{\mathrm{TM}}$ instrument, to a more modern lab-on-chip microfluidic platforms like the Bioanalyzer ${ }^{\mathrm{TM}} 2100$ (Agilent Technologies, USA) and Experion ${ }^{\mathrm{TM}}$ (Bio-Rad Laboratories, USA).

Owing to the invariable low yields in extracting RNA from environmental samples, quantification and assessment of nucleic acids are more pre-disposed towards protocols which consume fewer amounts of the sample. This makes logical sense as there are always inherent procedural difficulties in extracting high quality RNA from environmental samples, forcing the end user to judiciously make use of the nucleic acid sample. Of the methods available for RNA assessment, the spectrophotometric methods using UV/ VIS are the most popular and are performed at multiple wavelengths to assess truly the quality of the extracted RNA. Being non-discriminative, spectrophotometric quantification is done at $240 \mathrm{~nm}$ (background absorption and possible contamination), $260 \mathrm{~nm}$ (specific for nucleic acids), $280 \mathrm{~nm}$ (specific for proteins) and $320 \mathrm{~nm}$ (background absorption and possible contamination). On the basis of absorption at $260 \mathrm{~nm}$, the quantity, and by the ratio at other wavelength values, namely $A_{260 n m} / A_{280 n m}, A_{260 n m} / A_{240 n m}$ and $A_{260 n m} /$ $A_{320 \mathrm{~nm}}$, the purity can be assessed (Fleige and Pfaffl, 2006). $A_{260 n m} / A_{280 n m}$ ratio $>1.8$ is considered an acceptable indicator of good RNA yield, suitable for downstream RT-qPCR analysis. However, it cannot determine the presence of contaminating inhibitors, which has to be empirically determined. This method however, has one major drawback- its inability to discern between RNA and carryover genomic DNA which, also contributes to the absorption value at $260 \mathrm{~nm}$. This contamination could lead to serious overestimation (less than $50 \%$ accuracy) of the final RNA amounts in samples containing carryover DNA, bringing into question the reliability of this widely used estimation parameter (Bustin and Nolan, 2004). A more modern approach to correct this anomaly has been the use of advanced instrumentation in conjunction with RNA specific dyes. The NanoDrop ND-3300 instrument from NanoDrop Technologies, is an example of this approach and is increasingly becoming popular amongst researchers. RNA specific dyes like the RiboGreen ${ }^{\mathrm{TM}}$ dye (Molecular Probes, USA) can be used to detect RNA in conjunction with the NanoDrop quantification instrument. The main advantage of this quantification approach being the low requirement of sample $(1-2 \mu \mathrm{l})$ and the ability of the instrument to read spectra over a wide-range $(240-700 \mathrm{~nm})$ on a single run.

The aforementioned spectrophotometric assessment methods, both conventional and modern, have one major drawback- the difficulty in assessing the integrity of the RNA preparation in the sample. Assessment by resolving the RNA sample on a denaturation agarose gel, to visually 
inspect the integrity of the $18 \mathrm{~S} / 28 \mathrm{~S}$ or $16 \mathrm{~S} / 25 \mathrm{~S}$ ribosomal RNA, is one possible approach. This however is extremely impractical if the experimental set-up is high throughput or if the sample amount is limiting. Both these are woefully unsuitable for assessing RNA extracted from environmental samples which generally are high-throughput and precious.

Themodernlab-on-chiptechnologiesholdsmuch promise and is able to alleviate all the aforementioned drawbacks inherent to conventional quantification methodologies. The Agilent 2100 Bioanalyzer and the Experion system are part of this new generation of technologies which allows the end user to assess the RNA sample's quality, quantity and most importantly, its integrity (18S/28S or $16 S / 25 S$ rRNA). All the quantifications are performed on a micro-fabricated chip which requires extremely small amounts of starting sample. The development of a RNA assessment quality parameter called the RNA integrity number (RIN) for the Agilent 2100 Bioanalyzer (Agilent Technologies, 2004; Schroeder et al., 2006), is a step in the right direction to develop parameter(s) which, could be reliably used to compare the quality of starting samples. Since it is easy to directly compare samples which are submitted to RT-qPCR analysis, such universal parameters serve another important functionmake it simpler for laboratories to cross collaborate and compare results. These quantification platforms although extremely accurate and promising, are however expensive. This makes it difficult to implement them in experimental situations which require high throughput quantification of the starting sample or for laboratories operating on a modest research budgets.

\section{Inhibitors from environmental matrices: diversity and mitigation}

Notwithstanding the difficulties in extracting high quality intact RNA from environmental matrices, one invariant factor an environmental microbiologist has to always contend with is the presence of substrate derived chemical inhibitors (reviewed by de Franchis et al., 1988; Wilson 1997; Filion et al., 2003; Sutlovic et al., 2005). These chemical compounds are natural components of the environmental matrices and are invariably co-extracted with RNA preparation. The passive presence of these chemical moieties in the final RNA preparation has one unintended consequence-inhibition of the downstream RT-qPCR enzymatic reaction, including the reverse transcription reaction which is required for generating the cDNA template (Johnson et al., 2005). Practically speaking, inhibition per se during the whole RT-qPCR work flow could also be the end consequence of other factors which are of 'non-sample' origin, for example poorly controlled reaction conditions, contaminants in reagents, user derived introduction of contamination or some complex interactions that, at best are difficult to describe or distinguish (Wilson, 1997). In the present context, we have sought to focus on the substrate (i.e. environmental matrix) derived inhibitors and their effect on downstream enzymatic reaction.

Till date, a wide range of these endogenous chemical inhibitors have been identified from different environmental matrices (reviewed by Wilson, 1997). The list of known inhibitors presented in this review, however, does not include any process/protocol introduced chemical moieties like phenol, EDTA, CTAB etc., which are also inhibitory to the enzymatic components of RT-qPCR (Demeke and
Jenkins, 2010). Empirical extraction of nucleic acids from various environmental substrates carried out till date has made it fairly possible to predict, assuming the elimination is not total, the nature of inhibitor(s) which, may be present in the final RNA preparation. For example, one can expect the presence of 'brown contaminating' and humic/fulvic acidsbased substances in RNA preparations originating from organic soil and sediments (Watson and Blackwell, 2000). Similarly, polyphenols and tannins based inhibitors are endemic to wines and fermented beverages (Zoecklein et al., 1999; Phister and Mills, 2003; Delaherche et al., 2004; Martorell et al., 2005) and therefore, expected to get coextracted during the RNA extraction protocol. As a result, an intuitive decision making process goes into selecting an optimal RNA extraction protocol, for a particular target environmental matrix. If an optimized protocol is unavailable, a specific RNA extraction protocol has to be 'tailored' for the target matrix, so that an efficient mitigation of the expected inhibitory factor(s) known to be prevalent within the target matrices could be achieved.

Mitigating the effects of endogenous inhibitors on RT-qPCR, co-extracted during RNA extraction, is one of the major challenges faced by researchers. Since it is difficult to describe the quantitative levels of a particular inhibitor(s) present within a target matrix sample, especially those sourced naturally, a two pronged inhibitor mitigation strategy is generally employed by most researchers. As a first part of this strategy, and the most logical, is the development of RNA extraction protocol(s) which, not only are capable of extracting high-quality, intact RNA, but are also able to efficiently sequester any matrix originating inhibitors (Bürgmann et al., 2003; Monnet et al., 2008; Ulve et al., 2008). Considering the wide range and complexities amongst environmental matrices per se, tailoring any extraction protocol to yield high quality RNA, which is not only intact, but also inhibitor-free, has proven to be an extremely challenging undertaking.

Based on literature evidence, the most common strategy has been to use specific chemicals/additives in the RNA extraction protocol itself which, bind/adsorb to the inhibitor(s). In this way, a large load of inhibitors are removed during the extraction process itself, making the final RNA preparations virtually free of or having a very minimum amounts of chemical inhibitors. This 'preemptive' strategy is widely employed and some of the common examples of the chemicals which aid in reducing/ eliminating the endogenous load of inhibitors are: acid phenol-chloroform-isoamyl alcohol $(25: 24: 1)$ to remove inhibitors from sediments and soils (Tsai and Olson, 1991), $\mathrm{AINH}_{4}\left(\mathrm{SO}_{4}\right)_{2}$ to reduce co-purification of PCR inhibitors (Braid et al., 2003), a combination of $5 \%$ polyethylene glycol 8000 (PEG), polyvinylpolypyrrolidone (PVPP) and Sepharose 4B-polyvinylpolypyrrolidone spin columns (Arbeli and Fuentes, 2008), polymeric adsorbent Superlite DAX-8 (Schriewer et al., 2011), flotation of substrate (Jacobson et al., 2009), commercial glass milk, lonex and membranebased spin columns (Tsai and Olson, 1991; Wiedbrauk et al., 1995; Braid et al., 2003). These approaches have been found to be optimal for those environmental matrices where the level of target transcript(s) is relatively high. This being important as the use of these inhibitor adsorption chemicals requires one to use multiple phase extraction/elution steps. Such multistep recovery processes, result in a considerable 
loss of nucleic acids, making it difficult to detect moderate to rare transcripts.

The aforementioned mitigation strategies, although successful in most of the cases, work especially well when the target matrices have a simpler composition, for example water, or if the extraction matrices originate from highly controlled in vitro experimental set-ups. When highly complex environmental matrices like natural organic soils; organic sediments/sludge are used, which are known to carry a very heavy load of endogenous inhibitors, this mitigation approach is generally found to be inadequate. As a result, additional steps are deemed necessary to completely alleviate the effects of the inhibitor(s) which, do get co-extracted in the final RNA preparation. A very common strategy to achieve this goal is through the use of additives which bind/chelate the inhibitors in the RT-qPCR reaction itself. However for this strategy to work, the additive should be compatible with the enzymatic components of the RT-qPCR reaction itself. Identifying such novel additives, which are not only highly efficient in quenching the actions of an inhibitor, but compatible with the other enzymatic components of the RT-qPCR reaction, has been a major challenge. Some of the amplification facilitators/additives identified till date, which are able to satisfy these stringent requirements include the use of 'inhibitor tolerating' DNA polymerases (Al-Soud and Rådström, 1998), like bovine serum albumin (BSA) and single-stranded DNA binding T4 gene 32 protein (Kreader, 1996), bovine lacto transfer technique optimizer (BLOTTO) and spermidine, amongst others (Wang et al., 2007). Irrespective of which one of these aforementioned strategies is employed; one of the most basic approach has always been to serially dilute the RNA sample to overcome the inhibitory effects of the endogenous inhibitor (Tsai and Olson, 1992; QueipoOrtuno et al., 2008). This simple approach, in conjunction to the aforementioned approaches, works well in most of the cases, however, this strategy is feasible only when the target transcript is present in high copy numbers. Excess dilution can lead to false negatives when targets are diluted below their detection limits or when the inhibitor(s) cannot be diluted to levels below their interference threshold (Queipo-Ortuno et al., 2008).

Of the plethora of inhibitory moieties identified during RNA extraction from environmental matrices, very little is known about the actual mechanism through which this inhibition takes place. It is generally assumed that an inhibitor generally acts at multiple steps of the whole RTqPCR analysis process. These steps could broadly be divided into three categories: (1) the nucleic acid extraction step, where it prevents complete cell lysis leading to an unrepresentative sampling; (2) the capture step, where RNA is recovered leading to an inefficient recovery or degradation; and, finally, (3) at the individual enzymatic step(s) of the RTqPCR protocol which results in signal dampening. Since it is sometimes difficult to define an inhibition phenomenon at both the lysis and capture phases, the most logical target to characterize an inhibitor(s), has been to assay for any changes (usually negative), in the fidelity of the RT-qPCR enzymes, including the reverse transcriptase (RT) enzyme used for generating the cDNA.

Based on the multistep enzymatic cascade of RT-qPCR, the interaction of the inhibitor could itself be elucidated into three potential steps: (1) binding of the inhibitor to the enzymes of RT-qPCR namely: reverse transcriptase and DNA polymerase; (2) interaction of the inhibitor with the DNA; and finally (3) the interaction with the polymerase during primer extension cycle. This categorization is by no means absolute, since an inhibitor may act in more than one way and relationships between chemical, enzymatic, and physical factors often cannot be distinguished (Wilson, 1997). It is also probable that many inhibitors act through various physical and chemical means by interfering with the interaction between DNA and polymerase, for example $1 \mathrm{ng}$ of humic acid is known to inhibit Taq DNA polymerase and reverse transcriptase (Opel et al., 2010). Other factors which directly affect the components of the RT-qPCR are nucleases which hydrolyse DNA, divalent ions which bind to the co-factors required for the functioning of the polymerase, polyamines which prevent the DNA polymerase to access the template, amongst others (reviewed by Wilson, 1997; Hugget et al., 2008).

\section{Examples of common environmental matrices}

A quick meta-analysis of those studies where GPCR and RT-qPCR techniques have been implemented to quantify microorganisms from environmental matrices, reveal a striking disparity- a much larger number of studies used DNA as a target instead of mRNA. This large scale bias in the use of DNA rather than RNA based targets could be attributed to the innate difficulties in extracting inhibitor-free RNA, as described in great detail in the earlier sections. Specifically, the compounded inefficiencies usually associated with RNA extraction from environmental matrices, the problem of accessing the cells enmeshed within the matrix component (for lysis to release of nucleic acids), high prevalence of endogenous RNase's, the extreme labiality of RNA species and co-extraction of inhibitors, could be some of the technical difficulties which in our opinion tip a researcher to favour DNA based targets. Despite these 'substrate defined' technical bottlenecks, it's highly satisfying to note that many attempts have indeed been made till date, in analysing the in situ microbial gene expression from various environmental matrices.

Amongst the host of RNA based gene transcripts as a target for RT-qPCR analysis, the choice of ribosomal RNA (rRNA) to infer the physiological status of a microorganism has certainly been very controversial (Smith et al., 2006). Though, it is difficult for us to justify or debunk the validity of any study carried out till date where, modulation of a particular rRNA transcript(s) has successfully been used to describe the physiological functioning of the target microorganism(s), arguments certainly compelling against this approach, cannot be ignored. One of primary argument being the well known fact that the copy number of rRNA operons varies widely within a genome, therefore measuring the rRNA transcript numbers is not an accurate 'reflection of the functional processes' carried out by the target organism (Smith et al., 2006). Also, the transcription rates of the rRNA is regulated by resource availability (Klappenbach et al., 2000), for example starved cells tend to keep their ribosomal machinery active for a longer time (Wagner et al., 2003), thereby potentially skewing the actual gene expression results. To circumvent such technical problems, functional genes are now being seen as more logical targets in other areas of microbiology, including environmental microbiology (Bælum et al., 2008; Nicolaisen et al., 
2008). Keeping these caveats in mind and avoiding any unnecessary complications, we have in the future sections, only considered those studies where mRNA transcripts have been used as targets to analyse endogenous microbial gene expression from environmental matrices using RTqPCR. Some of these common environmental matrices are described below.

\section{Soil}

Soil is home to highly diverse, complex microbial communities, which provide immense ecological services to mankind and its functioning, both direct and indirect, deeply impact many biological and bio-geochemical processes (Gutknecht etal., 2006). Because of this importance, amongst all the known environmental matrices where the RT-qPCR technology has been implemented, it either pertains to soil or matrices derived from it. This is despite severe technical handicaps usually associated with working with this matrix, for example heavy compositional complexity and presence of chemical inhibitors, amongst others. Since only $1 \%$ of the endogenous soil microbial population is cultivable (Davis et al., 2005), the acute gap in our information pertaining to the exact genetic makeup of the target microorganism(s), makes it even more challenging to design specific RT-qPCR primers/probes when soil is the substrate in question.

With specific reference to soils, one overarching question molecular microbiologists have constantly been interested in is the possibility of developing a quantitative understanding of both the abilities and diversity of complex natural soil microbial communities, preferably under in situ conditions (Bælum et al., 2006; Bælum and Jacobsen, 2009). While some headway has been made in addressing this question, the introduction of RT-qPCR, a molecular tool with an undeniable ability to analyse target microorganism(s) with an extreme high specificity, sensitivity and rapidity, has given a tremendous boost to one's ability to address this seemingly simple, yet technically intractable question. The latter being primarily attributed to the high compositional complexity and intrinsic diversity amongst natural soil matrices per se. Notwithstanding this technical challenge, such understanding is extremely important if one needs to define the precise 'structure-function' relationship amongst soil based microbial communities. Of all the studies carried out till date, two distinct experimental approaches could be seen: (a) in situ gene expression experiments, where the expression of the target gene(s) is analysed directly from the natural soils and (b) seeding experiments, where the natural soil samples are seeded with a specific test microbe and its expression studied under defined test conditions.

An in situ analysis of microbial gene expression is seen as the 'holy grail' by many interested in understanding the endogenous microbial structure-function relationship (Bælum et al., 2006). Owing to low efficiency of RNA extraction, high prevalence of endogenous inhibitors and rapid degradation of mRNA, especially when working with natural field soils, realization of this goal has not been possible as one would have expected (Bælum et al., 2006). As a result, most gene expression studies have tended to use soil matrices with low concentrations of co-extractable enzymatic inhibitors, organic radicals or nucleases (Holmes 2004; Steunou et al., 2006; Smith et al., 2007). Despite this, researchers still have attempted, and in some cases succeeded, in analysing soils matrices, e.g. peat soil for microbial gene expression which, earlier were thought to be intractable due to their harsh endogenous constituents (Freitag and Prosser, 2009).

Understanding the in situ temporal expression of a gene has a special significance in certain area of soil microbiology, for example bio-remediation where such understanding is important to implicate the role of a gene in the actual mineralization/degradation process. An illustrative example could be the work of Holmes et al. (2004), who showed that it's possible to monitor the in situ changes in the expression pattern of the nifD gene in Geobacteraceae present in aquifer sediment in response to fluctuating sources of nitrogen. When these in situ results were compared with the highly controlled laboratory experimental set-ups, the in situ expression rate of the nifD gene was close to 100fold higher. The authors suggested that there are 'unknown factors' operating in natural systems which, cannot be mimicked under controlled conditions. In other words, if an effective bio-remediation strategy has to be formulated using Geobacteraceae; one needs to understand the expression pattern of the nifD gene preferably under in situ conditions. This study underscores the utility of in situ systems to understand the exact metabolic state of the target microorganism. Similar studies where transcription dynamics of microbial genes have been assessed in situ using RT-PCR targeted atz $A$ and atz $D$ genes expression involved in the bio-degradation of the pesticide atrazine in the soil drilosphere, which essentially is a soil influenced by earthworm secretions (Monard et al., 2010), alkB (alkane monooxygenase) involved in the microbial degradation of hydrocarbons in Antarctic soils (Powell et al., 2006) and the mcrA (methyl coenzyme $\mathrm{M}$ reductase) and $p m o A$ (methane monooxygenase) genes involved in the methanogenesis process in peat soils (Freitag and Prosser, 2009; Freitag et al., 2010) amongst others (Bælum et al., 2008; Chin et al., 2008; O'Neil et al., 2008; Mårtensson et al., 2009; Mouser et al., 2009; DiDonato et al., 2010; Liu et al., 2010a,b; N'Guessan et al., 2010; Paulin et al., 2010; Yuan et al., 2011). The methanogenesis study in peat soils (Freitag and Prosser, 2009; Freitag et al., 2010) is especially notable, considering the extreme difficulties in working with peatbased substrates. Components of peat soil are detrimental for RT-qPCR analysis since it is difficult to extract high-quality nucleic acids, owing to its high acidity $(\mathrm{pH} 3.8)$, high water content (80-90\%), high concentrations of co-extractable organic matter, high capacity of complexing nucleic acids (Crecchio and Stotzky, 1998) and high concentrations of stable free radicals (Shinozuka et al., 2001) and phenolics (Vaughan and Ord, 1982).

Limited numbers of spiking experiments have also been reported whereby; natural soil is first seeded with a test microorganism (containing the gene(s) of interest) and then, transcriptional modulation of the(se) gene(s) monitored using RT-qPCR. Subsequent work where such type of approach has been taken include quantification of invA mRNA in Salmonella spp. seeded in soil and chicken manure (Jacobsen and Holben, 2007; García et al., 2010); herbicide degradation genes in Cupriavidus necator (Nicolaisen et al., 2008), subsurface sediment (Holmes et al., 2004; Elifantz et al., 2010), bphAa gene involved in the degradation of polychlorinated biphenyl (PCB) in Rhodococcus sp. strain RHA1 (Wang et al., 2008), tfdC and C230 genes involved in the cleavage of the of the 
pollutant 2,4-D (Lillis et al., 2010), and more recently, the expression of two antibiotic encoding biosynthetic genes in the bacterium Pseudomonas sp. LBUM300 of biocontrol interest (DeCoste et al., 2011; Novinscak and Filion, 2011).

\section{Food and other edible matrices}

Microbial gene expression using RT-PCR in food and water based matrices (e.g. beef, chicken, carbonated beverages, fresh produce, wine, drinking water) is mainly performed for biosafety and surveillance purposes (Fratamico, 2001; Straub and Chandler, 2003; Rowan, 2011); as part of mandates usually delegated to governmental regulatory authorities (USFDA, 2001; WHO, 2002). In the interest of public safety at large and the societal importance of food and water, microbiological testing of these matrices is not only expected to be very rapid, but also extremely accurate (Jaykus, 2003). With the ability to acquire data in real-time, coupled with no post-sample processing, the RT-qPCR technology is an ideal technique to further this goal. Despite some initial cost concerns viz à viz the traditional protocols which are generally slower and cumbersome to perform, the RT-qPCR technology is now a widely accepted analytical tool in determining food microbial biosafety (Jaykus, 2003; Hanna et al., 2005). The implementation of the RT-qPCR technology, specifically addresses the accuracy factor also interpreted as the 'zero tolerance' policy in the food microbial biosafety industry. Departure from such excruciatingly high verification standards could result in an erosion of consumer confidence, leading to potential severe economic consequences to both- producer and the end consumer.

Viability status of the target microorganism is extremely critical to accurately determine the biosafety status of a food sample (Keer and Birch, 2003). The conventional cultivation protocol even though highly cumbersome, specifically addresses this aspect, and therefore continues to be a mainstay technique in food microbiology (Harrigan, 1998). The relatively non-specific and time consuming aspect of this approach affects the decision making process in determining the biosafety status of food samples. As a result, alternatives are constantly being sought, which do not suffer from some of the logistical drawbacks. The advent of PCR changed this and offered a viable alternative to these cultivation based protocols (Krascsenicsova et al., 2008). Initially, the PCR based protocols made extensive use of DNA based targets, including ribosomal (rDNA) in microbial food biosafety sciences (Vaitilingom et al., 1998; Fortin et al., 2001; Rijpens and Herman, 2002; Yaron and Matthews, 2002; Rodriguez-Lazaro et al., 2003; Malorny et al., 2007). Though able to detect the presence/absence of the target microorganism, this DNA based approach falls short in determining the viability status of the target microorganism. As viability per se is critical in accurately determining the biosafety status of food/water, decisions which have solely relied on DNA-based data, have attracted a great deal of controversy (Drahovska et al., 2001) and continues to do so (Fey et al., 2004). One major criticism against this approach is the well known fact that DNA is able to persist in dead cells, and therefore any positive PCR signal could potentially be contaminated, or at worst originate wholly from these non-viable, dead cells (Gonzalez-Escalona et al., 2009). To avoid such confounding situations, non-DNA targets have been proposed and for that matter, less stable mRNA offers a much more attractive alternative (Sheridan et al., 1998).

As mentioned earlier, expression analysis of functional gene transcripts allows one not only to detect the presence/ absence of the target microorganism within a food sample, but also to infer its viability (Fey et al., 2004). In food-based matrices, for mRNA per se to be a reliable target for RTqPCR and an accurate indicator of cell metabolic status, it should meet certain criteria. These criteria could be summarized as:

1 For specificity purposes, the target mRNA transcription should be species or strain specific.

2 The target mRNA transcription should have a sufficiently brief half-life, so as to allow its detection.

3 The target mRNA transcription should ideally be expressed at sufficiently high copy numbers.

4 Its expression pattern should have some correlation with well-defined physiological parameters (typically spoilage).

Identifying candidate transcripts which are able to satisfy all the aforementioned criteria's, has proven to be an extremely difficult undertaking for food microbiologists. Thus, it is not surprising to note that there aren't many studies in the literature where RT-qPCR has been used to assess microbial gene expression in food/water based matrices. This difficulty in identifying a candidate mRNA could also be one reason where researchers have been forced to use the rRNA targets for determining the biosafety status of food (Hierro et al., 2006; Wan et al., 2006), despite the well known fact that rRNA expression is not too tightly linked to the physiological status of an organism (Ruimy et al., 1994; Gourse et al., 1996) and hence, not an ideal reliable indicator of cell viability status (Fey et al., 2004, Gonzalez-Escalona et al., 2009). Most, if not all the studies which have sought to assess the biosafety status of a particular food sample using mRNA based targets, have invariably made use of the 'endpoint reporting method' i.e. conventional agarose gel electrophoresis (Vaitilingom et al., 1998; Fortin et al., 2001; Yaron and Matthews, 2002). Though highly invaluable from a scientific stand point, these reverse transcriptionPCR (RT-PCR) studies would have spurred, as one might expect, a rapid adaptation of the RT-qPCR technology, to further enhance the dynamics and accuracy of detecting the target microorganism(s), in the area of food microbial biosafety. However, looking at the number of studies in the literature, this 'natural progression' leading to a widescale adaptation of the RT-qPCR technology, has not yet happened. The main reasons cited behind this application gap, is the high set up and implementation costs of the RTqPCR platform (Jaykus, 2003; Hanna et al., 2005) and the exceptionally low tolerance for false-positive results in the area of food biosafety which is not totally difficult to rule out, considering the highly sensitive nature of this fluorescencebased detection technique.

Bleve et al. (2003), for the first time implemented the RT-qPCR technique along with the conventional endpoint RT-PCR technique to quantify yeast and mould contaminants in yogurts and other pasteurized fruit-derived products (fruit juices and preserves). Yeast and mould based microorganisms have been heavily implicated in food spoilage and contamination. Using the fungal specific actin (act) transcripts as target, they were able to show that 
it is possible to detect viable and viable but not culturable (VBNC) cells from food samples. No signal was however detected from dead cells. The dynamics of this detection was very interesting and depended on the nature of the detection system employed. Specifically, the RT-PCR was able to detect $10 \mathrm{CFU} / \mathrm{ml}$ and $10^{2}-10^{3} \mathrm{CFU} / \mathrm{ml}$ of the fungi in pure culture and artificially contaminated food products, respectively. However, when the RT-qPCR system was used, the detection limit was raised 10- to 1000-fold higher, for the same target and extraction matrices. The authors noted that the extremely large dynamic range of detection, typical for RT-qPCR, is the key towards offsetting some of the limitations of the RT reaction, which is inherently vulnerable to inhibition by some of the matrix components (e.g. nucleases, fats, low $\mathrm{pH}$, and chelating $\mathrm{Mg}^{2+}$ ions), used in this particular study. Other examples of RT-qPCR-based assessment of endogenous microbial gene expression in processed foods include: quantification of the sea and sed gene transcripts encoding enterotoxins $A$ and $D$ to quantify Staphylococcus aureus in cheese and milk (Duquenne, 2010), meat (Dolan et al., 2010), pork (Techathuvanan et al., 2010) and finally, Salmonella spp. in chicken and eggs (Wang and Mustapha, 2010).

In the realm of unprocessed foods/water-based matrices, there are few examples to be found where RT-qPCR has been used to determine the endogenous microbial gene expression. Excellent examples of unprocessed matrices are fresh vegetable products (e.g. raw salads) and drinking water. While fresh products are consumed raw with minimal pre-treatment, water is subject to microbial contamination either at source or during distribution to end consumers. In other words, it is an important vehicle for transmission of a large number of microbial borne diseases and therefore a subject of constant surveillance by regulatory authorities (Straub and Chandler, 2003; Howard et al., 2006; Fong et al., 2007). Fey et al. (2004) showed for the first time that it was possible to detect Salmonella enterica serovar Typhimurium using RT-qPCR in environmental water samples, using two RNA targets: the mRNA encoding for the invA (invasion protein A) gene and 16S rRNA. Notwithstanding the successful demonstration by these authors of RT-qPCR to detect microbial gene expression in water, there have been no further reported studies on similar lines, except for the detection of water based RNA viruses (Baert et al., 2008; Parshionikar et al., 2010). One major reason for this could be the technical difficulties in concentrating the target microorganisms from very large volumes of water (typically $100 \mathrm{ml}$ to 1 litre), so as to get enough biomass for a representative and reproducible extraction of RNA (Rutjes et al., 2005). Other examples of RT-qPCR in water based matrices are for the presence of yeast in wine (Hierro et al., 2006) and juice based products (Connor et al., 2005; Wan et al., 2006). Both these studies made use of rRNA as targets to detect the viability status of the targeted microorganisms. Similarly, RT-qPCR has been used for detection of various serovars of $S$. enterica in raw vegetables and fresh products, specifically spinach (Gonzalez-Escalona et al., 2009) and peppers (Miller et al., 2010), targeting the invA gene transcripts.

\section{Environmental biosolids/sludge}

Analysis of microbial gene expression in biosolids/faecal samples is done primarily as public biosafety measures to detect the active presence of microbes which are known to affect human health. Most of the studies done till date on these environmental matrices have been qualitative, i.e. detect the presence/absence of the target microbial pathogen (Novinscak et al., 2008; Karpowicz et al., 2009). Recovery of RNA from biosolids/sludge is difficult due to endemic presence of array of inhibitors like humic acids, fulvic acids, fats, and proteins (Rosen et al., 1992; Tsai and Olson, 1992; Whitehouse and Hottel, 2007). Environmental biosolids, especially urban sludge, is known to contain a heavy load of these substances, in addition to numerous organic/inorganic compounds, such as polyphenols and heavy metals (USEPA, 2000). These compounds have been found to get concentrated with microbial activity, resulting in its co-extraction during RNA extraction (Rock et al., 2010). Owing to these reasons, analysis of microbial gene expression in biosolids using RT-qPCR is extremely difficult and predictably very few studies on this substrate can be found in literature (Dunaev et al., 2008; Matsuda et al., 2009; Kubota et al., 2010; Rock et al., 2010).

\section{Conclusions}

It is beyond doubt that there has been resurgence in the application of nucleic acid targeting tools in every aspect of biology, owing to reduced technology costs, constant development of effective nucleic acids recovery protocols, which also include commercial options, and last but not the least, the ever increasing access to post-analysis processing systems, i.e. software, online databases. These aforementioned advancements have however failed to provide the necessary traction for researchers working in the area of environmental microbiology, owing to certain difficulties endemic to this area of research. Of several, two major issues which have made it difficult to rapidly introduce advanced molecular tools in this area: (a) limited genetic information of environmental microbes due to extremely low cultivability and (b) practical difficulties in extracting high quality nucleic acids from environmental matrices, suitable for sensitive application like RT-qPCR. Despite these 'cultivation-defined' and 'substrate-dependent' technical bottlenecks, DNA/RNA targeting molecular tools, mainly end-point PCR-based, have extensively been used to analyse the expression status of targeted microbial transcripts. Though qualitative, these preliminary studies have given us invaluable insights into the functioning of the target microbe under defined experimental conditions.

To overcome some of the well known technical limitations of end-point PCR, detection platforms like RT-qPCR have proven to be an ideal solution. Using this highly versatile technology, it is now possible to simultaneously detect and quantify in real-time, the expression pattern of a microbial transcripts isolated from environmental substrates. Practical difficulties in working with environmental matrices have however impeded our ability to robustly apply this versatile technology. Technical issues such as extraction of inhibitor-free, structurally intact, total RNA from environmental substrates which is suited for a sensitive technique like RT-qPCR, continues to be a major impediment. It is however satisfying to note that despite these severe 'substrate defined' limitations, several attempts have indeed been made to implement the RT-qPCR technology in environmental microbiology. Efforts like these have given us invaluable insights into the 
expression status of a particular transcript and hence, the biological functioning of microbes, specifically under natural in situ conditions. In summary, a better understanding of the technical difficulties faced by microbiologist in working with environmental matrices, especially those sourced naturally, should go a long way in developing efficient mitigation strategies (Filion, 2012).

\section{References}

Agilent Technologies. (2004). DNA, RNA, protein and cell analysis. Agilent application note, publication number 5989-1197EN.

Al-Soud, W.A., and Rådström, P. (1998). Capacity of nine thermostable DNA polymerases to mediate DNA amplification in the presence of PCR-inhibiting samples. Appl. Environ. Microbiol. 64, 3748-3753.

Arbeli, Z., and Fuentes, C.L. (2008). Improved purification and PCR amplification of DNA from environmental samples. Int. Biodeterior. Biodegrad. 62, 14-14.

Bælum, J., and Jacobsen, C.S. (2009). TaqMan probe-based real-time PCR Assay for detection and discrimination of class I, II, and III tfdA genes in soils treated with phenoxy acid herbicides. Appl. Environ. Microbiol. 75, 2969-2972.

Bælum, J., Henriksen, T., Hansen, H.C.B., and Jacobsen, C.S. (2006). Degradation of 4-chloro-2-methylphenoxyacetic acid in top-and subsoil is quantitatively linked to the class III tfdA gene. Appl. Environ. Microbiol. 72, 1476-1486.

Bælum, J., Nicolaisen, M.H., Holben, W.E., Strobel, B.W., Sørensen, J., and Jacobsen, C.S. (2008). Direct analysis of $t f d A$ gene expression by indigenous bacteria in phenoxy acid amended agricultural soil. ISME J. 2, 677-687.

Baert, L., Wobus, C.E., Van Coillie, E., Thackray, L.B., Debevere, J., and Uyttendaele, M. (2008). Detection of murine noro virus 1 by using plaque assay, transfection assay, and real-time reverse transcription-PCR before and after heat exposure. Appl. Environ. Microbiol. 74, 543-546.

Bakken, L.R., and Frostegård, Å. (2006). Nucleic acid extraction from soil. In Soil Biology, Nannipieri, P., and Smalla, K., eds (Springer, Berlin, Germany), pp. 49-73.

Bakken, L.R., and Lindahl, V.S. (1995). Recovery of bacterial cells from soil. In Nucleic Acids in the Environment, Methods and Application: Laboratory Manual, Trevors, J.T., and Van Elsas, J.D., eds (Springer, Berlin, Germany), pp. 8-27.

Bleve G., Rizzotti, L., Dellaglio, F., and Torriani, S. (2003). Development of reverse transcription (RT)-PCR and realtime RT-PCR assays for rapid detection and quantification of viable yeasts and molds contaminating yogurts and pasteurized food products. Appl. Environ. Microbiol. 69, 4116-4122.

Braid M.D., L.M. Daniels and C.L. Kitts, (2003) Removal of PCR inhibitors from soil DNA by chemical flocculation, J. Microbiol. Methods 52, 389-393.

Bürgmann, H., Widmer, F., Sigler, W.V., and Zeyer. J. (2003). mRNA extraction and reverse transcription-PCR protocol for detection of nifH gene expression by Azotobacter vinelandii in soil. Appl. Environ. Microbiol. 69, 1928-1935.

Bustin, S.A. (2002). Quantification of mRNA using realtime reverse transcription PCR (RT-PCR): trends and problems. J. Mol. Endocrinol. 29, 23-39.

Bustin, S.A., and Nolan, T. (2004). Template handling, preparation, and quantification, In The Real-Time PCR
Encyclopedia A-Z of Quantitative PCR, Bustin, S.A., ed. (International University Line, La Jolla, CA), pp. 87-120.

Bustin, S.A., Benes, V., Nolan, T., and Pfaffl, M.W. (2005). Quantitative real-time RT-PCR-a perspective. J. Mol. Endocrinol. 34, 597-601.

Chin, K.J., Sharma, M.L., Russell, L.A., O'Neill, K.R., and Lovley, D.R. (2008). Quantifying expression of a dissimilatory (bi) sulfite reductase gene in petroleumcontaminated marine harbor sediments. Microb. Ecol. 55, 489-499.

Connor, C.J., Luo, H., Gardener, B.B., and Wang, H.H. (2005). Development of a real-time PCR-based system targeting the 16S rRNA gene sequence for rapid detection of Alicyclobacillus spp. in juice products. Int. J. Food Microbiol. 99, 229-235.

Crecchio, C., and Stotzky, G. (1998). Binding of DNA on humic acids: effect on transformation of Bacillus subtilis and resistance to DNase. Soil Biol. Biochem. 30, 10611067.

Davis, K.E., Joseph, S.J., and Janssen, P.H. (2005). Effects of growth medium, inoculum size, and incubation time on culturability and isolation of soil bacteria. Appl. Environ. Microbiol. 71, 826-834.

DeCoste, N.J., Gadkar, V.J., Filion, M. (2011). Relative and absolute quantitative real-time PCR-based quantifications of $h c n C$ and phID gene transcripts in natural soil spiked with Pseudomonas sp. strain LBUM300. Appl. Environ. Microbiol. 77, 41-47.

Deer, D.M., Lampel, K., and González-Escalona, N. (2010). $A$ versatile internal control for use as DNA in real-time PCR and as RNA in real-time reverse transcription PCR assays. Lett. Appl. Microbiol. 50, 366-372.

Delaherche, A., Claisse, O., and Lonvaud-Funel, A. (2004). Detection and quantification of Brettanomyces bruxellensis and 'ropy' Pediococcus damnosus strains in wine by real-time polymerase chain reaction. J. Appl. Microbiol. 97, 910-915.

Demeke, T., and Jenkins, G.R. (2010). Influence of DNA extraction methods, PCR inhibitors and quantification methods on real-time PCR assay of biotechnologyderived traits. Anal. Bioanal. Chem. 396, 1977-1990.

DiDonato, R.J. Jr., Young, N.D., Butler, J.E., Chin, K-J., Hixson, K.K., Mouser, P., Lipton, M.S., DeBoy, R., and Methé, B.A. (2010). Genome sequence of the delta proteobacterial strain NaphS2 and analysis of differential gene expression during anaerobic growth on naphthalene. PLoS ONE Genome 19, e14072.

Dolan, A., Burgess, C.M., Fanning, S., and Duffy, G. (2010). Application of quantitative reverse-transcription PCR (qRT-PCR) for the determination of the total viable count (TVC) on meat samples. J. Appl. Microbiol. 109, 91-98.

van Doorn, R., Klerks, M.M., van Gent-Pelzer, M.P., Speksnijder, A.G., Kowalchuk, G.A., and Schoen, C.D. (2009). Accurate quantification of microorganisms in PCR-inhibiting environmental DNA extracts by a novel internal amplification control approach using Biotrove OpenArrays. Appl. Environ. Microbiol. 75, 7253-7260.

Drahovska, H., Turna, J., Piknova, E., Kuchta, T., Szitasova, I., Skarkova, A., and Sasik, M. (2001). Detection of Salmonella by polymerase chain reaction targeted to fimC gene. Biologia 56, 611-616.

Dunaev, T., Sevda, A., and Metin, D. (2008). Gene expression monitoring for detection and quantification of viable but 
non-culturable pathogens in biosolids. Proceedings of the Water Environment Federation, Residuals and Biosolids 11, 1053-1063.

Duquenne, M., Fleurot, I., Aigle, M., Darrigo, C., BorezeeDurant, E., Derzelle, S., Bouix, M., Deperrois-Lafarge, V., and Delacroix-Buchet, A. (2010). Tool for quantification of Staphylococcal enterotoxins gene expression in cheese. Appl. Environ. Microbiol. 76, 1367-1374.

Elifantz, H., N'Guessan, L.A., Mouser, P.J., Williams, K.H., Wilkins, M.J., Risso, C., Holmes, D.E., Long, P.E., and Lovley, D.R. (2010). Expression of acetate permeaselike (apl) genes in subsurface communities of Geobacter species under fluctuating acetate concentrations. FEMS Micro. Ecol. 73, 441-449.

Fey, A., Eichler, S., Flavier, S., Christen, R., Hofle, M.G., and Guzman, C.A. (2004). Establishment of a real-time PCRbased approach for accurate quantification of bacterial RNA targets in water, using Salmonella as a model organism. Appl. Environ. Microbiol. 70, 3618-3623.

Filion, M. (2012). Quantitative Real-time PCR in Applied Microbiology (Norfolk, UK: Caister Academic Press).

Filion, M., St-Arnaud, M., and Jabaji-Hare, S.H. (2003). Direct quantification of fungal DNA from soil substrate using real-time PCR. J. Microbiol. Methods 53, 67-76.

Fleige, S., and Pfaffl, M.W. (2006). RNA integrity and the effect on the real-time qRT-PCR performance. Mol. Asp. Med. 27, 126-139.

Fleming, J.T., and Sayler, G.S. (1995). Assessment of gene expression in the environment: quantitative mRNA analysis in contaminated soils. In Applications of Molecular Biology in Environmental Chemistry, Minear, R.A., Ford, A.M., Needham L.L., and Karch, N.J., eds (Lewis Publishers, New York), pp. 45-58.

Fong, T.T., Mansfield, L.S., Wilson, D.L., Schwab, D.J., Molloy, S.L., and Rose, J.B. (2007). Massive microbiological groundwater contamination associated with a waterborne outbreak in Lake Erie, South Bass Island, Ohio. Environ. Health Perspect. 115, 856-864.

Fortin, N.Y., Mulchandani, A., and Chen, W. (2001). Use of real-time polymerase chain reaction and Molecular beacons for the detection of Escherichia coli $\mathrm{O} 157: \mathrm{H} 7$. Anal. Biochem. 289, 281-288.

de Franchis, R., Cross, N.C., Foulkes, N.S., and Cox, T.M. (1988). A potent inhibitor of Taq polymerase co-purifies with human genomic DNA. Nucleic Acids Res. 16, 10355.

Fratamico, P.M. (2001). Applications of the polymerase chain reaction for detection, identification, and typing of food borne microorganisms. In Microbial Food Contamination, Wilson, C.L., and Droby, S., eds (CRC Press, New York), pp. 95-99.

Freitag, T.E., and Prosser, J.I. (2009). Correlation of methane production and functional gene transcriptional activity in a peat soil. Appl. Environ. Microbiol. 75, 66796687.

Freitag, T.E., Toet, S., Ineson, P., and Prosser, J.I. (2010). Links between methane flux and transcriptional activities of methanogens and methane oxidizers in a blanket peat bog. FEMS Microbiol. Ecol. 73, 157-165.

Frostegård, A., Courtois, S., Ramisse, V., Clerc, S., Bernillon, D., Le Gall, F., Jeannin, P., Nesme, X., and Simonet, P. (1999). Quantification of bias related to the extraction of DNA directly from soils. Appl. Environ. Microbiol. 65, 5409-5420.
García, R., Bælum, J., Fredslund, L., Santorum, P., and Jacobsen, C.S. (2010). Influence of temperature and predation on survival of Salmonella enterica Serovar Typhimurium and expression of invA in soil and manureamended soil. Appl. Environ. Microbiol. 76, 5025-5031.

González-Escalona, N., Hammack, T.S., Russel, M., Jacobson, A.P., De Jesús, A.J., Brown, E.W., and Lampel, K.A. (2009). Detection of live Salmonella sp. cells in produce by a TaqMan-Based quantitative reverse transcriptase real-time PCR targeting invA mRNA. Appl. Environ. Microbiol. 75, 3714-3720.

Gourse, R.L., Gaal, T., Bartlett, M.S., Appleman, J.A., and Ross, W. (1996). rRNA transcription and growth rate-dependent regulation of ribosome synthesis in Escherichia coli. Annu. Rev. Microbiol. 50, 645-677.

Gutknecht, J.L.M., Goodman, R.M., and Balser, T.C. (2006). Linking soil process and microbial ecology in freshwater wetland ecosystems. Plant and Soil. 289, 17-34.

Hahn, D., Kester, R., Starrenburg, M.J.C., and Akkermans, A.D.L. (1990). Extraction of ribosomal RNA from soil for detection of Frankia with oligonucleotide probes. Arch. Microbiol. 154, 329-335.

Hanna, S.E., Connor, C.J., and Wang, H.H. (2005). Realtime polymerase chain reaction for the food microbiologist: technologies, applications, and limitations. J. Food Sci. 70, R49-R53.

Harrigan, W.F. (1998). Laboratory Methods in Food Microbiology, 3rd edition (Academic press, New York).

Hierro, N., Esteve-Zarzoso, B., Gonzalez, A., Mas, A., and Guillamón, J.M. (2006). Real-time quantitative PCR (QPCR) and reverse transcription-QPCR for detection and enumeration of total yeasts in wine. Appl. Environ. Microbiol. 72, 7148-7155.

Holmes, D.E., Nevin, K.P., and Lovley, D.R. (2004). In situ expression of nifD in Geobacteraceae in subsurface sediments. Appl. Environ. Microbiol. 70, 7251-7259.

Hoorfar, J., Cook, N., Malorny, B., Wagner, M., De Medici, D., Abdulmawjood, A., and Fach, P. (2003). Making internal amplification control mandatory for diagnostic PCR. J. Clin. Microbiol. 41, 5835.

Hoorfar, J., Cook, N., Malorny, B., Wagner, M., De Medici, D., Abdulmawjood, A., and Fach, P. (2004). Diagnostic PCR: making internal amplification control mandatory. Lett. Appl. Microbiol. 38, 79-80.

Howard, G., Bartram, J., Pedley, S., Schmoll, O., Chorus, I., and Berger, P. (2006). Groundwater and public health. In Protecting groundwater for health: managing the quality of drinking-water sources, Schmoll, O., Howard, G., Chilton, J., and Chorus, I., eds (IWA Publishing, London), pp. 3-19.

Hugget, J.F., Novak, T., Garson, J.A., Green, C., MorrisJones, S.D., Miller, R.F., and Zumla, A. (2008). Differential susceptibility of $P C R$ reactions to inhibitors: an important and unrecognized phenomenon. BMC Res. Notes. 1, 70.

Hurt, R.A., Qiu, X., Wu, L., Roh, Y., Palumbo, A.V., Tiedje, J.M., and Zhou, J. (2001). Simultaneous recovery of RNA and DNA from soils and sediments. Appl. Environ. Microbiol. 67, 4495-4503.

ljzerman, M.M., Dahling, D.R., and Fout, G.S. (1997). A method to remove environmental inhibitors prior to the detection of waterborne enteric viruses by reverse transcription-polymerase chain reaction. J. Virol. Meth. 63, 145-153. 
Imbeaud, S., Graudens, E., Boulanger, V., Barlet, X., Zaborski, P., Eveno, E., Mueller, O., Schroeder, A., and Auffray, C. (2005). Toward standardization of RNA quality assessment using user-independent classifiers of microcapillary electrophoresis traces. Nucleic Acids Res. 33, e56.

Jacobsen, C.S., and Holben, W.E. (2007). Quantification of mRNA in Salmonella sp. seeded soil and chicken manure using magnetic capture hybridization RT-PCR. J. Microbiol. Methods 69, 315-321.

Jacobson, M., Norling, B., Gunnarson, A., and Aspan, A. (2009). Flotation-a new method to circumvent PCR inhibitors in the diagnosis of Lawsonia intracellularis. Int. J. Microbiol. 2009, 410945.

Jaykus, L. (2003). Challenges to developing real-time methods to detect pathogens in foods. ASM News 69, 341-347.

Johnson, D.R., Lee, P.K.H., Holmes, V.F., and AlvarezCohen, L. (2005). An internal reference technique for accurately quantifying specific mRNAs by real-time PCR with application to the tce $A$ reductive dehalogenase gene. Appl. Environ. Microbiol. 71, 3866-3871.

Karpowicz, E., Novinscak, A., Bärlocher, F., and Filion, M. (2010). qPCR quantification and genetic characterization of Clostridium perfringens populations in biosolids composted for 2 years. J. Appl. Microbiol. 108, 13652672.

Keer, J.T., and Birch, L. (2003). Molecular methods for the assessment of bacterial viability. J. Microbiol. Methods 53, 175-183.

Klappenbach, J.A., Dunbar, J.M., and Schmidt, T.M. (2000). rRNA operon copy number reflects ecological strategies of bacteria. Appl. Environ. Microbiol. 66, 1328-1333.

Krascsenicsova, K., Piknova, L., Kaclikova, E., and Kuchta, T. (2008). Detection of Salmonella enterica in food using two-step enrichment and real-time polymerase chain reaction. Lett. Appl. Microbiol. 46, 483-487.

Kreader, C.A. (1996). Relief of amplification in PCR with bovine serum albumin or T4 gene 32 protein. Appl. Environ. Microbiol. 62, 1102-1106.

Kubota, H., Tsuji, H., Matsuda, K., Kurakawa, T., Asahara, T., and Nomoto, K. (2010). Detection of human intestinal catalase-negative, gram-positive cocci by rRNA-targeted reverse transcription-PCR. Appl. Environ. Microbiol. 76, 5440-5451.

Lillis, L., Clipson, N., and Doyle, E. (2010). Quantification of catechol dioxygenase gene expression in soil during degradation of 2, 4-dichlorophenol. FEMS. Microbiol. Ecol. 73, 363-369.

Liu, B., Mørkved, P.T., Frostegård, Å., and Bakken, L.R. (2010a). Denitrification gene pools, transcription and kinetics of $\mathrm{NO}, \mathrm{N}_{2} \mathrm{O}$ and $\mathrm{N}_{2}$ production as affected by soil pH. FEMS Microbiol. Ecol. 72, 407-417.

Liu, Y.J., Zaprasis, A., Liu, S.J., Drake, H.L., and Horn, M.H. (2010b). The earthworm Aporrectodea caliginosa stimulates abundance and activity of phenoxyalkanoic acid herbicide degraders. The ISME J. 5, 473-485.

Malorny, B., Bunge, C., and Helmuth, R. (2007). A real-time PCR for the detection of Salmonella enteritidis in poultry meat and consumption eggs. J. Microbiol. Methods 70, 245-251.

Mårtensson, L., Díez, B., Wartiainen, I., Zheng, W., ElShehawy, R., and Rasmussen, U. (2009). Diazotrophic diversity, nifH gene expression and nitrogenase activity in a rice paddy field in Fujian, China. Plant and Soil 325, 207-218.

Martorell, P., Querol, A., and Fernández-Espinar, M.T. (2005). Rapid identification and enumeration of Saccharomyces cerevisiae species directly from wine by real-time PCR. Appl. Environ. Microbiol. 71, 6823-6830.

Matsuda, K., Tsuji, H., Asahara, T., Matsumoto, K., Takada, T., and Nomoto, K. (2009). Establishment of an analytical system for the human fecal microbiota, based on reverse transcription-quantitative PCR targeting of multicopy rRNA molecules. Appl. Environ. Microbiol. 75, 1961-1969.

Mouser, P.J., N'Guessan, A.L., Elifantz, H., Holmes, D.E., Williams, K.H., Wilkins, M.J., Long, P.E., and Lovley, D.R. (2009). Influence of heterogeneous ammonium availability on bacterial community structure and the expression of nitrogen fixation and ammonium transporter genes during in situ bioremediation of uranium-contaminated groundwater. Environ. Sci. Tech. 43, 4386-4392.

Miller, N.D., Draughon, F.A., and D'Souza, D.H. (2010). Real-time reverse-transcriptase-polymerase chain reaction for Salmonella enterica detection from Jalapeño and Serrano peppers. Foodborne Pathogens and Disease. 7, 367-373.

Monard, C., Martin-Laurent, F., Devers-Lamrani, M., Lima, O., Vandenkoornhuyse, P., and Binet, F. (2010). atz gene expressions during atrazine degradation in the soil drilosphere. Mol. Ecol. 19, 749-759.

Monnet, C., Ulve, V., Sarthou, A.S., and Irlinger. F. (2008). Extraction of RNA from cheese without prior separation of microbial cells. Appl. Environ. Microbiol. 74, 5724-5730.

N'Guessan, A.L., Elifantz, H., Nevin, K.P., Mouser,.PJ., Methé, B., Woodard, T.L., Manley, K., Williams, K.H., Wilkins, M.J., Larsen, J.T., et al. (2010). Molecular analysis of phosphate limitation in Geobacteraceae during the bioremediation of a uranium-contaminated aquifer. ISME J. 4, 253-266.

Nicolaisen, M.H., Bælum, J., Jacobsen, C.S., and Sørensen, J. (2008). Transcription dynamics of the functional $t f d A$ gene during MCPA herbicide degradation by Cupriavidus necator AEO106 (pRO101) in agricultural soil. Environ. Microbiol. 10, 571-579.

Nolte, F.S. (2004). Novel internal controls for real-time PCR assays. Clin. Chem. 50, 801-802.

Novinscak, A., and Filion, M. (2011). Effect of soil clay content on RNA isolation and detection and quantification of bacterial gene transcripts in soil using qRT-PCR. Appl. Environ. Microbiol. 77, 6249-6252.

Novinscak, A., Surette, C., Allain, C., and Filion, M. (2008). Application of molecular technologies to monitor the microbial content of biosolids and composted biosolids. Water Sci. Tech. 57, 471-477.

Ogram, A., Sun, W., Brockman, F.J., and Fredrickson, J.K. (1995). Isolation and characterization of RNA from lowbiomass deep-subsurface sediments. Appl. Environ. Microbiol. 61, 763-768.

O'Neil, R.A., Holmes, D.E., Coppi, M.V., Adams, L.A., Larrahondo, M.J., Ward, J.E., Nevin, K.P., Woodard, T.L., Vrionis, H.A., N'Guessan, A.L., and Lovley, D.R. (2008). Gene transcript analysis of assimilatory iron limitation in Geobacteraceae during groundwater bioremediation. Environ. Microbiol. 10, 1218-1230.

Opel, K.L., Chung, D., and McCord, B.R. (2010). A study 
of PCR inhibition mechanisms using real time PCR. J. Forensic Sci. 55, 25-33.

Parshionikar, S., Laseke, I., and Fout, G.S. (2010). Use of propidium monoazide in reverse transcriptase PCR to distinguish between infectious and noninfectious enteric viruses in water samples. Appl. Environ. Microbiol. 76, 4318-4326.

Paulin, M.M., Nicolaisen, M.H., and Sørensen, J. (2010). Abundance and expression of enantioselective $r d p A$ and $\operatorname{sdp} A$ dioxygenases genes during degradation of the racemic herbicide (R,S)-2-(2,4-Dichlorophenoxy) propionate in soil. Appl. Environ. Microbiol. 76, 28732883.

Phister, T.G., and Mills, D.A. (2003). Real-time PCR assay for detection and enumeration of Dekkera bruxellensis in wine. Appl. Environ. Microbiol. 69, 7430-7434.

Powell, S.M., Ferguson, S.H., Bowman, J.P., and Snape, I. (2006). Using real-time PCR to assess changes in the hydrocarbon-degrading microbial community in Antarctic soil during bioremediation. Microbial Ecol. 52, 523-532.

Queipo-Ortuno, M.I., Colmenero, J.D.D., Macias, M., Bravo, M.J., and Morata, P. (2008). Preparation of bacterial DNA template by boiling and effect of immunoglobulin $G$ as an inhibitor in real-time PCR for serum samples from patients with brucellosis. Clin. Vacc. Immunol. 15, 293-296.

Raeymarkers, L. (1993). Quantitative PCR: theoretical consideration with practical implication. Anal. Biochem. 214, 582-585.

Rijpens, N.P., and Herman, L.M. (2002). Molecular methods for identification and detection of bacterial food pathogens. J. AOAC Int. 85, 984-995.

Rock, C., Alum, A., and Abbaszadegan, M. (2010). PCR inhibitor levels in concentrates of biosolid samples predicted by a new method based on excitation-emission matrix spectroscopy. Appl. Env. Microbiol. 76, 8102-8109.

Rodriguez-Lazaro, D., Hernandez, M., Esteve, T., Hoorfar, J., and Pla, M. (2003). A rapid and direct real time PCRbased method for identification of Salmonella spp. J. Microbiol. Methods 54, 381-390.

Rossen, L., Norskov, P., Holmstrom, K., and Rasmussen, O.F. (1992). Inhibition of PCR by components of food samples, microbial diagnostic assays and DNA-extraction solutions. Int. J. Food Microbiol. 17, 37-45.

Rowan, N.J. (2011). Defining established and emerging microbial risks in the aquatic environment: current knowledge, implications, and outlooks. Int. J. Microbiol. 46, 2832.

Ruimy, R., Breittmayer, V., Boivin, V., and Christen, R. (1994). Assessment of the state of activity of individual bacterial cells by hybridization with a ribosomal RNA targeted fluorescently labeled oligonucleotidic probe. FEMS Microbiol. Ecol. 15, 207-213.

Rutjes, S.A., Italiaander, R., van den Berg, H.H.J.L., Lodder, W.J., and de Husman, R.A.M. (2005). Isolation and detection of enterovirus RNA from large-volume water samples by using the NucliSens miniMAG System and real-time nucleic acid sequence-based amplification. Appl. Environ. Microbiol. 71, 3734-3740.

Sambrook, J., and Russel, D.W. (2001). Molecular Cloning: A Laboratory Manual (CSH Laboratory Press, Cold Spring Harbor, New York).

Schoor, O., Weinschenk, T., Hennenlotter, J., Corvin, S., Stenzl, A., Rammensee, H.-G., and Stevanovic, S. (2003).
Moderate degradation does not preclude microarray analysis of small amounts of RNA. Biotechniques 35, 1192-1201.

Schriewer A., Wehlmann, A., and Wuertz, S. (2011). Improving qPCR efficiency in environmental samples by selective removal of humic acids with DAX-8. J. Microbiol. Methods 85, 16-21.

Schroeder, A., Mueller, O., Stocker, S., Salowsky, R., Leiber, M., Gassmann, M., Lightfoot, S., Menzel, W., Granzow, M., and Ragg, T. (2006) The RIN: an RNA integrity number for assigning integrity values to RNA measurements. BMC Mol. Biol. 7, 3.

Sharkey, F.H., Banat, I.M., and Marchant, R. (2004). Detection and quantification of gene expression in environmental bacteriology. Appl. Environ. Microbiol. 70, 3795-3806.

Sheridan, G.E.C., Masters, C.I., Shallcross, J.A., and Mackey, B.M. (1998). Detection of mRNA by reverse transcription-PCR as an indicator of viability in Escherichia coli cells. Appl. Environ. Microbiol. 64, 1313-1318.

Shinozuka, T., Enomoto, Y., Hayashi, H., Andod, H., and Yamaguchi, T. (2001). Variation of free radical concentrations of peat humic acid by methylation. In Humic Substances, Structures, Models and Functions, Ghabbour, E.A., and Davies, G., eds (RSC Publishing, Cambridge, UK), pp. 83-93.

Smith, C.J., Nedwell, D.B., Dong, L.F., and Osborn, A.M. (2006). Evaluation of quantitative polymerase chain reaction-based approaches for determining gene copy and gene transcript numbers in environmental samples. Environ. Microbiol. 8, 804-815.

Smith, C.J., Nedwell, D.B., Dong, L.F., and Osborn, A.M. (2007). Diversity and abundance of nitrate reductase genes (narG and napA), nitrite reductase genes (nirS and $n r f A$ ), and their transcripts in estuarine sediments. Appl. Environ. Microbiol. 73, 3612-3622.

Steunou, A.-S., Bhaya, D., Bateson, M.M., Melendrez, M.C., Ward, D.M., Brecht, E., Peters, J.W., Kühl, M., and Grossman, A.R. (2006). In situ analysis of nitrogen fixation and metabolic switching in unicellular thermophilic cyanobacteria inhabiting hot spring microbial mats. Proc. Natl. Acad. Sci. U.S.A. 103, 2398-2403.

Straub, T.M., and Chandler, D.P. (2003). Towards a unified system for detecting waterborne pathogens. J. Microbiol. Methods 53, 185-197.

Suslov, O., and Steindler, D.A. (2005). PCR inhibition by reverse transcriptase leads to an overestimation of amplification efficiency. Nucleic Acids Res. 33, e181.

Sutlović, D., Definis, G.M, Andelinović, S., Gugić, D., and Primorac, D. (2005). Taq polymerase reverses inhibition of quantitative real time polymerase chain reaction by humic acid. Croat. Med. J. 46, 556-562.

Takayama, K., and Kjelleberg, S.A. (2000). The role of RNA stability during bacterial stress responses and starvation. Environ. Microbiol. 2, 355-365.

Techathuvanan, C., Draughon, F.A., and D'Souza, D.H. (2010). Real-time reverse transcriptase PCR for the rapid and sensitive detection of Salmonella typhimurium from pork. J. Food Prot. 73, 507-514.

Tsai, Y.L., and Olson, B.H. (1992). Rapid method for separation of bacterial DNA from humic substances in sediments for polymerase chain reaction. Appl. Environ. Microbiol. 58, 2292-2295. 
Ulve, V.M., Monnet, C., Valence, F., Fauquant, J., Falentin, H., and Lortal, S. (2008). RNA extraction from cheese for analysis of in situ gene expression of Lactococcus lactis. J. Appl. Microbiol. 105, 1327-1333.

USFDA U.S. Food and Drug Administration. (2001). Food Code. Washington, D.C.: Food and Drug Administration. Available from: <http://www.cfsan.fda.gov/ dms/fc01-toc. html

U.S. Environmental Protection Agency. (2000). Supplementary guidance for conducting health risk assessment of chemical mixtures. Report no. USEPA/630/R-00/002. National Center for Environmental Assessment, Office of Research and Development, U.S. (EPA, Washington, DC).

Vaitilingom, M., Gendre, F., and Brignon, P. (1998). Direct detection of viable bacteria, molds and yeasts by reverse transcriptase PCR in contaminated milk samples after heat treatment. Appl. Environ. Microbiol. 64, 1157-1160.

Vaughan, D., and Ord, B.G. (1982). An in vitro effect of soil organic matter fractions and synthetic humic acids on the generation of superoxide radicals. Plant Soil 66, 113-116.

Wagner, M., Horn, M., and Daims, H. (2003). Fluorescence in situ hybridization for the identification and characterization of prokaryotes. Curr. Opin. Microbiol. 6, 302-309.

Wan, K., Yousef, A.E., Schwartz, S.J., and Wang, H.H. (2006). Rapid, specific, and sensitive detection of spoilage molds in orange juice using a real-time TaqMan PCR assay. J. Food Prot. 69, 385-390.

Wang L., and Mustapha, A. (2010). EMA-real-time PCR as a reliable method for detection of viable Salmonella in chicken and eggs. J. Food Sci. 75, M134-M139.

Wang, M.Y., Olson, B.H., and Chang, J.S. (2007). Improving $\mathrm{PCR}$ and $\mathrm{qPCR}$ detection of hydrogenase $\mathrm{A}$ (hydA) associated with Clostridia in pure cultures and environmental sludges using bovine serum albumin, Appl. Microbiol. Biotechnol. 77, 645-656.
Wang, Y., Shimodaira, J., Miyasaka, T., Morimoto, S., Oomori, T., Ogawa, N., Fukuda, M., and Fujii, T. (2008). Detection of bphAa gene expression of Rhodococcus sp. strain RHA1 in soil using a new method of RNA preparation from soil. Biosci. Biotechnol. Biochem. 72, 694-701.

Watson, R.J., and Blackwell, B. (2000). Purification and characterization of a common soil component which inhibits the polymerase chain reaction. Can. J. Microbiol. 46, 633-642.

Whitehouse, C.A., and Hottel, H.E. (2007). Comparison of five commercial DNA extraction kits for the recovery of Francisella tularensis DNA from spiked soil samples. Mol. Cell. Probes 21, 92-96.

Wiedbrauk, D.L., Werner, J.C., and Drevonc, A.M. (1995). Inhibition of PCR by aqueous and vitreous fluids. J. Clin. Microbiol. 33, 2643-2646.

Wilson, I.G. (1997). Inhibition and facilitation of nucleic acid amplification. Appl. Environ. Microbiol. 63, 3741-3751.

World Health Organization. (2002). The World Health Report. Reducing Risks, Promoting Healthy Life (World Health Organization, Geneva, Switzerland).

Yaron, S., and Matthews, K.R. (2002). A reverse transcriptase-polymerase chain reaction assay for detection of viable Escherichia coli O157:H7: investigation of specific target genes. J. Appl. Microbiol. 92, 633-640.

Yuan, Y., Conrad, R., and Lu, Y. (2011). Responses of methanogenic archaeal community to oxygen exposure in rice field soil. Environ. Micro. Rep. 1, 345-347.

Zhou, J., Bruns, M.A., and Tiedje, J.M. (1996). DNA recovery from soils of diverse composition. Appl. Environ. Microbiol. 62, 316-322.

Zoecklein, B.W., Fugelsang, K.C., Gump, B.H., and Nery, F.S. (1999). Wine Analysis and Production (Aspen Publishers, New York). 


\section{Further Reading}

Caister Academic Press is a leading academic publisher of advanced texts in microbiology, molecular biology and medical research. Full details of all our publications at caister.com

- MALDI-TOF Mass Spectrometry in Microbiology Edited by: M Kostrzewa, S Schubert (2016) www.caister.com/malditof

- Aspergillus and Penicillium in the Post-genomic Era Edited by: RP Vries, IB Gelber, MR Andersen (2016) www.caister.com/aspergillus2

- The Bacteriocins: Current Knowledge and Future Prospects Edited by: RL Dorit, SM Roy, MA Riley (2016)

www.caister.com/bacteriocins

- Omics in Plant Disease Resistance Edited by: V Bhadauria (2016) www.caister.com/opd

- Acidophiles: Life in Extremely Acidic Environments Edited by: R Quatrini, DB Johnson (2016) www.caister.com/acidophiles

- Climate Change and Microbial Ecology: Current Research and Future Trend

Edited by: J Marxsen (2016)

www.caister.com/climate

- Biofilms in Bioremediation: Current Research and Emerging Technologies

Edited by: G Lear (2016)

www.caister.com/biorem

- Microalgae: Current Research and Applications Edited by: MN Tsaloglou (2016) www.caister.com/microalgae

- Gas Plasma Sterilization in Microbiology: Theory, Applications, Pitfalls and New Perspectives Edited by: H Shintani, A Sakudo (2016) www.caister.com/gasplasma

- Virus Evolution: Current Research and Future Directions Edited by: SC Weaver, M Denison, M Roossinck, et al. (2016) www.caister.com/virusevol

- Arboviruses: Molecular Biology, Evolution and Control Edited by: N Vasilakis, DJ Gubler (2016) www.caister.com/arbo

- Shigella: Molecular and Cellular Biology Edited by: WD Picking, WL Picking (2016) www.caister.com/shigella

-Aquatic Biofilms: Ecology, Water Quality and Wastewater Treatment

Edited by: AM Romaní, H Guasch, MD Balaguer (2016)

www.caister.com/aquaticbiofilms

- Alphaviruses: Current Biology

Edited by: S Mahalingam, L Herrero, B Herring (2016)

www.caister.com/alpha

- Thermophilic Microorganisms

Edited by: F Li (2015)

www.caister.com/thermophile
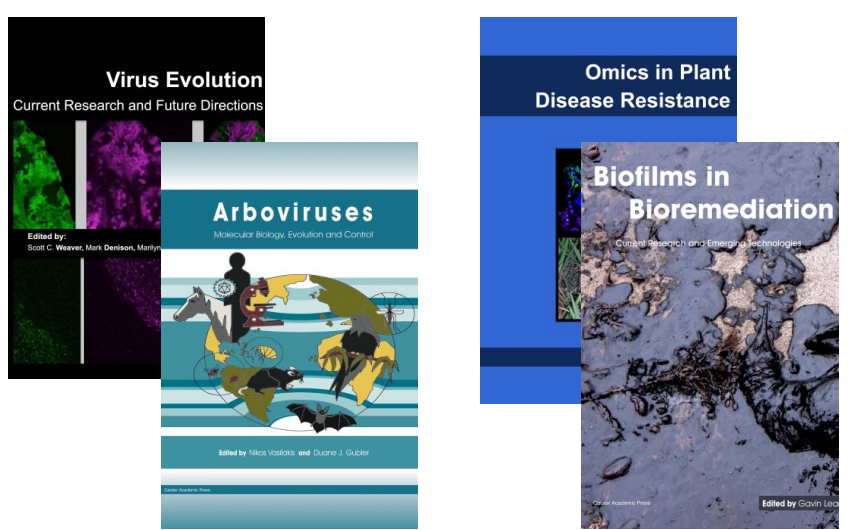
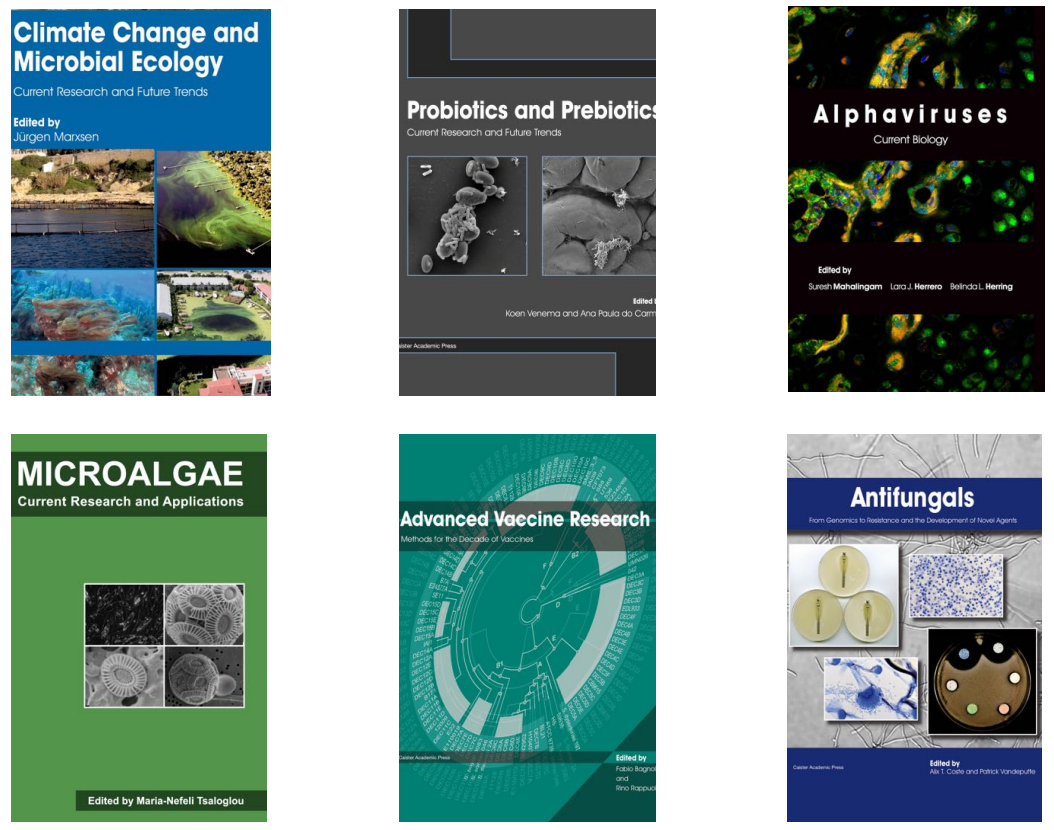

- Flow Cytometry in Microbiology: Technology and Applications Edited by: MG Wilkinson (2015) www.caister.com/flow

- Probiotics and Prebiotics: Current Research and Future Trends Edited by: K Venema, AP Carmo (2015) www.caister.com/probiotics

- Epigenetics: Current Research and Emerging Trends Edited by: BP Chadwick (2015) www.caister.com/epigenetics2015

- Corynebacterium glutamicum: From Systems Biology to Biotechnological Applications

Edited by: A Burkovski (2015)

www.caister.com/cory2

- Advanced Vaccine Research Methods for the Decade of Vaccines

Edited by: F Bagnoli, R Rappuoli (2015)

www.caister.com/vaccines

- Antifungals: From Genomics to Resistance and the Development of Novel Agents

Edited by: AT Coste, P Vandeputte (2015)

www.caister.com/antifungals

- Bacteria-Plant Interactions: Advanced Research and Future Trends Edited by: J Murillo, BA Vinatzer, RW Jackson, et al. (2015) www.caister.com/bacteria-plant

\section{- Aeromonas}

Edited by: J Graf (2015)

www.caister.com/aeromonas

- Antibiotics: Current Innovations and Future Trends

Edited by: S Sánchez, AL Demain (2015)

www.caister.com/antibiotics

- Leishmania: Current Biology and Contro Edited by: S Adak, R Datta (2015) www.caister.com/leish2

- Acanthamoeba: Biology and Pathogenesis (2nd edition) Author: NA Khan (2015)

www.caister.com/acanthamoeba2

- Microarrays: Current Technology, Innovations and Applications Edited by: Z He (2014)

www.caister.com/microarrays2

- Metagenomics of the Microbial Nitrogen Cycle: Theory, Methods and Applications

Edited by: D Marco (2014)

www.caister.com/n2 